\title{
ADOPTION OF ECOSYSTEM-BASED MEASURES IN FARMLANDS - NEW OPPORTUNITIES FOR FLOOD RISK MANAGEMENT
}

\author{
Kr. Todorova* \\ Faculty of Natural Resource Economics, University of National and World Economy, Sofia, Bulgaria
}

\begin{abstract}
Ecosystem-based approach for flood risk management is a growing new field of research which has an emphasis on the role of ecosystems for the reduction of floods. One way of implementing this approach is by using the potential of farmlands to reduce and store run-off in a way that the water is retained within a certain catchment. In Europe during the last few years more and more attention has been paid on the role of agriculture for providing ecosystem services including flood risk reduction. Currently, one possibility for the implementation of the ecosystem approach in farmlands is the provision of the Common Agricultural Policy and more specifically the implementation of agri-environment measures. The aim of this paper is to present the potential for the adoption of ecosystem-based measures by examining the farmers' willingness to adopt agri-environment measures. The adoption behavior of farmers is analyzed on the base of a survey among 77 farmers in Iskar river catchment in Bulgaria.
\end{abstract}

Key words: agri-environment measures, ecosystem services, contingent valuation

\section{INTRODUCTION}

The role of ecosystem services for flood risk reduction

Ecosystem services play an important role in reducing disaster risk, including flood risk. The basics of the ecosystem approach lie down in the proper management of ecosystems and their services. The earliest references to this concept can be traced out to the mid-60s and the 70s (1-2). In 1981, Ehrlich and Ehrlich (3) note that the most important anthropocentric cause for the conservation of biodiversity is the role of micro-organisms, plants and animals to provide free ecosystem services without which society cannot exist. Ecosystem services are defined as those that contribute to pollination, climate regulation, water retention and flood control (4).

Over the last decade, the role of ecosystems for disaster risk reduction has been considered by some authors $(5,6)$ as well as by the United Nations Office for Disaster Risk Reduction, which underlines the important role of the ecosystem approach for disaster risk reduction strategies. Even more, in recent years terms

\footnotetext{
*Correspondence to: Kristina Todorova, Faculty of Natural Resource Economics, University of National and World Economy, Sofia, Bulgaria, 1700 Sofia, Studentski grad Hristo Botev, +359887 599159,ktodorova@unwe.bg
}

such as ecosystem-based approach for adaptation and ecosystem-based approach for disaster risk reduction have emerged. The ecosystem-based approach uses ecosystem services as a strategy to adapt to the adverse effects of climate change and to reduce flood risk. In this context, natural water retention measures use the ecosystem approach to help regulate surface run-off, enhance ecosystem resilience to climate change, create carbon stocks and improve biodiversity (7).

Rural areas, particularly farmlands, play a key role in flood risk management mainly due to the formation of surface water run-off on their territory (8). The even more increasing interest in the natural measures for flood risk reduction somehow coincides with the reforms in the Common Agricultural Policy of the European Union after 2013. There is a strong prerequisite for strengthening the link between flood risk management and the implementation of agrienvironment practices.

Different studies show the relationship between the formation of run-off and agricultural practices and, respectively, the risk of flooding $(8,9)$. Surface run-off is formed when the amount and intensity of rainfall exceeds the soil's ability to infiltrate water and when the soil has reached a level of full moisture (10). The change of the soil structure 
may reduce the storage capacity, and reduce its infiltration capacity (11). This in turn can lead to increased surface run-off (12).

\section{Mechanisms for implementing measures based} on the ecosystem approach

The national policies of many countries implement a set of adaptation measures to mitigate the effects of flood risk within farmlands (13). They are primarily aimed at using public investments for flood protection and improvement of drainage systems in agricultural land. Few policies are aimed at reducing floods from farmland, despite the availability of research findings on how land management influences floods (13). These include, for example, some of the measures part of the agri-environment payments, which have the potential to reduce surface water runoff by providing farmers with an economic incentive. These incentives are voluntary and are mainly aimed at controlling soil erosion but also have an effect on the regulation of run-off (13). One of the main mechanisms by which the provision of ecosystem services from farmlands can be ensured is by the two pillars of the Common Agricultural Policy - the green element for direct payments and the Rural Development Program. Public intervention in this case is justified by the fact that if some ecosystem services can be provided incidentally without targeted intervention, for others where there is insufficient supply, it is necessary to create an appropriate economic incentive. For these services, which by their nature are public goods, their application is supposed to be outside the mandatory requirements that farmers should comply with.

Figure 1 presents some of the key ways for delivering ecosystem services from farmlands. In general, there are three options (14):

- Incidentally provided ecosystem services - these occur when ecosystem services are produced alongside other farm activities that are not deliberately deliver by the farmer;

Compliance with legal requirements ecosystem services are maintained and delivered through mandatory compliance with certain environmental requirements;

Compensatory payments - these are necessary economic incentives to motivate the farmer to implement certain measures or activities.

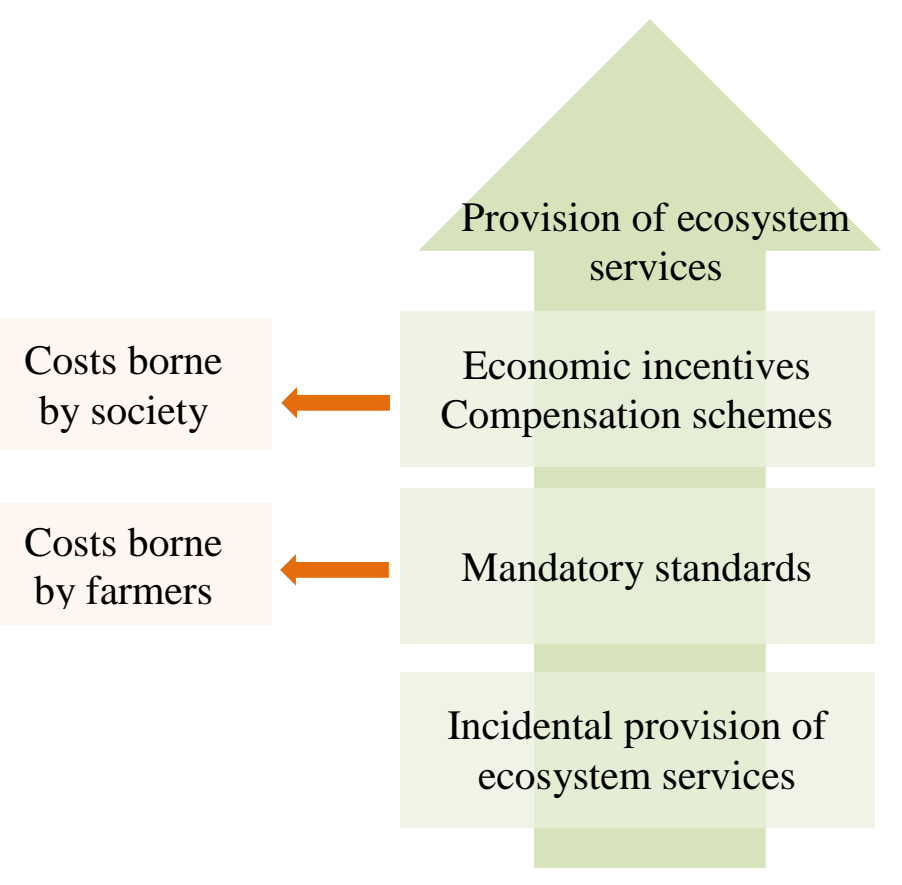

Source: Adapted following Cooper 2009

Figure 1. Provision of ecosystem services

In the form of payments for the implementation of certain agri-environmental measures, the public provision of such ecosystem services aims to compensate the farmer for the loss of benefits resulting from the implementation of a measure and the associated costs. This is in the form of a voluntary implementation of measures part of the Rural Development Program, which is part of Pillar 2 of the Common Agricultural Policy.

\section{MATERIALS AND METHODS}

In this study three types of agri-environment measures have been studied - buffers strips, crop rotation along contours (strip-cropping) and conversion of arable land into permanent 
grassland. All of them are part of the submeasure "Control of soil erosion" part of Agroecology and climate of the Rural development program 2014-2020.

One of the methods most commonly used to reveal the willingness of farmers to adopt a conservation measure is the contingent valuation. This is a non-market method that aims to reveal the minimum level of compensation a farmer is willing to accept to implement a measure that is accompanied by certain costs and lost profits. The main objective of contingent valuation is to disclose the preference of respondents in monetary terms through the maximum level of willingness to pay or the minimum level of compensation for a change in the quality or quantity of a commodity / service (15). The main application of this method is to evaluate the benefits of goods that are not exchanged through the market mechanism. Critics of the approach point out that the respondent is faced with a hypothetical choice that could make it difficult to reveal real behavior. However, in this specific study, the choice of the respondents cannot be considered hypothetical as there are real conditions for participation in a specific agri-environment measures, part of the Rural Development Program (16). Therefore it is presumed that farmers are aware of the need for finding a compromise between the production of food and the delivery of ecosystem services.

The approach for measuring willingness to pay, part of the contingent valuation, reveals the maximum that the respondent is willing to pay to avoid a change, while the willingness to accept compensation shows the minimum needed to cover the loss from the change. In this study, it is more appropriate to disclose the minimum level that can offset the loss of income that would occur when an agrienvironment measure is implemented by a farmer. In this way, the individual utility of a farmer is valued by his preferences.

There are several options for revealing the desired level of compensation which can motivate farmers to implement a specific measure. The question for revealing the minimum compensation can be asked in several ways: open-ended, iterative bidding game, payment card and single or doublebounded dichotomous choice. In this study the iterative bidding was chosen. This approach reveals the minimum level of compensation. Compared to the open format, iterative bidding makes it easier for respondents to choose whether to accept or reject a given level. If the respondent accepts it, the interviewer records it as the minimum level of compensation which the respondent is ready to accept. If the respondent does not accept the initially set level, the interviewer continues to offer higher levels until the minimum desired level is revealed. The questions regarding the level of compensation are set at three different levels in ascending order until the respondent decides to accept the appropriate level (Figure 2).

Source: Author research

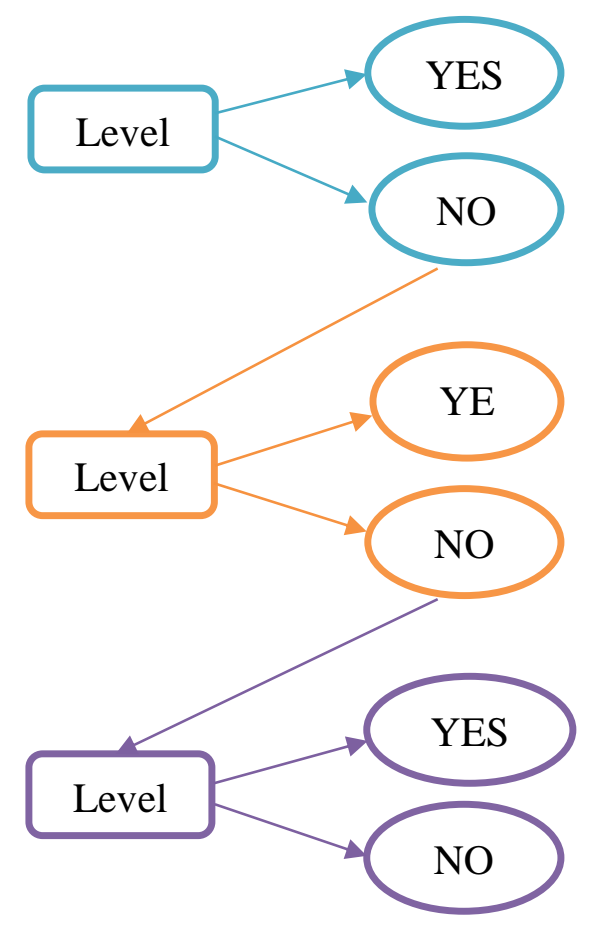

Figure 2. Elicitation of the appropriate level of compensation 
The benefits of this approach place the respondent in a situation where he will be able to decide more precisely whether the proposed level meets his preferences. It is important that the initial level is choosed carefully in order to be closer to the realistic conditions. Following the requirements of the European regulation No 1305/2013 on support for rural development by the European Agricultural Fund for Rural Development (EAFRD) the compensation levels shall compensate beneficiaries for all or part of the additional costs and income foregone resulting from the commitments made. This requirement means that it is necessary to take into account not only the incurred costs related to the implementation of the measure (additional costs) but also the lost income. Consequently, the amount of compensation should be due to the change in income resulting from the implementation of the new measure and the costs related to the implementation of this measure. Table 1 presents the compensation levels for the previous and current period of the Rural Development Program.

Table 1. Compensation levels in the Rural Development Program for the period 2007-2013 and 20142020

\begin{tabular}{|c|c|c|}
\hline Measure & RDP 2007-2013 & RDP 2014-2020 \\
\hline Buffer strips & 43 euro/ha & 40 euro/ha \\
\hline Strip-cropping & 45 euro/ha & 39.20 euro/ha \\
\hline $\begin{array}{c}\text { Conversion of arable land into permanent } \\
\text { grassland }\end{array}$ & 324 euro/ha & 315 euro/ha \\
\hline
\end{tabular}

Source: Ordinance 11 on the conditions and procedure for implementing measure 214 "Agri-environment payments" of the Rural Development Program for the period 2007 - 2013; Ordinance 7 on the conditions and procedure for implementing measure 10 "Agroecology and climate" of the Rural Development Program for the period $2014-2020$

The calculation of the compensation for the practice "buffer strips" is based on the costs for grass, maintenance costs, lost income from crop cultivation and potential income from haymaking. For the next measure - "stripcropping" - account is taken of the costs associated with the operation of agricultural machines due to incomplete machine grip and curvilineering of work moves. For the measure "conversion of arable land into permanent grassland", account is taken mainly of the losses from the transformation of the land in pasture, its maintenance and the income from the hay.

For the purposes of this study, respondents were asked about their hypothetical participation in a scheme for implementation of agri-environment activities aimed at regulating surface water run-off and reducing flood risk. Three levels have been defined as the first one corresponds to the one proposed by the Rural Development Program 20142020. The next two levels, respectively, exceed the initial one with $50 \%$ and $100 \%$. Rejection of the last level of compensation, which represents an increase of $100 \%$, implies unrealistic expectations of the respondents about the necessary compensation for the implementation of agri-environment activities. For the precise conducting of this method it is better to organize face to face interviews as well as by phone. For this purpose, 77 famers were contacted in the upper basin of the Iskar river.

\section{RESULTS}

The format set out in the questionnaire for the assessment of the willingness to accept certain level of compensation is based on the iterative bidding game. For the first measure - buffer strips - a compensation of 40 euro/ha is suggested for the first level and with 50\% and $100 \%$ higher for the next two levels. The highest percentage of the respondents - 57\% believe that the minimum level of compensation that could motivate them to implement the measure is 60 euro/ ha which is $50 \%$ higher than the initial one. These are the respondents who have denied the first level of compensation corresponding to the proposed in the Rural Development Program 2014-2020. About one third of the farmers accept the initial compensation level of 40 euro/ha. A small fraction of $9 \%$ of the respondents declined the first two levels and stated that the minimum level of compensation needed to motivate them to implement the measure is 80 euro/ ha. None of the respondents rejected all three levels of compensation. In regard to stripcropping a compensation of 40 euro/ha is suggested for the first level and 50\% and 100\% higher for the next two levels respectively. The highest percentage of the respondents - $48 \%$ believe that the minimum level of compensation that would motivate them to 
implement the measure is 60 euro/ ha. Of all the respondents, $41 \%$ accepted the initial level of compensation of, which is also proposed by the Rural Development Program. A small part of $11 \%$ of the respondents declined the first two levels and believe that the minimum level of compensation should be 80 euro/ ha. None of the respondents rejected all three levels of compensation. The results for both measures buffer strips and strip-cropping - are similar.

And finally, in regard to the measure for conversion of arable land into permanent grassland 315 euro/ha is suggested for the first level and 50\% and 100\% higher for the next two levels. All farmers accepted the initially set level of 315 euro/ ha. This makes the measure the most desirable to implement and with the most acceptable level of compensation. It can be concluded that this level of compensation most closely corresponds to the preferences of the farmers who took part in the survey, bearing in mind that compared to the other two measures, the maintenance of this one requires the least efforts.

\section{DISCUSSION}

The aim of this study is to reveal farmers willingness to accept compensation for the implementation of three agri-environment measures. These practices have a strong potential to regulate not only surface run-off and floods, but also soil erosion. A non-market method was used for revealing farmers preferences. The willingness to accept method reveals the minimum level of compensation a farmer is willing to accept to implement certain measure. The results of the study show similar outcome for two of the measures buffer strips and strip-cropping. It can be concluded that the prevailing part of the respondents are willing to accept compensation for the implementation of these two measures at the second level which corresponds to $50 \%$ higher in comparison with the initial one. Just a small fraction of the farmers believe that a higher level of compensation is needed -80 euro/ha which is a twofold increase in comparison with the one targeted in the Rural Development Program for the period 20142020. This leads to the conclusion that the majority of the farmers who took part in the survey believe that the level proposed by the Program is not enough to motivate them to implement these two measures. In comparison, the results for the conversion of arable land into permanent grassland show identical outcome for all respondents - 77 farmers pointed out that the initial level of 315 euro/ha is enough to motivate their participation in the scheme.

The results from the study give an insight into farmers' willingness to accept compensation for implementing agri-environment measures for flood risk reduction based on the ecosystem approach in the Iskar river basin. This method can be used in other areas and river basins in Bulgaria which will give more detailed information about farmers' preferences and willingness to adopt agri-environment measures.

\section{REFERENCES}

1. Carson, R., (1962), Silent spring

2. Fisher A.C., Krutilla, J., (1975), The Economics of Natural Environments. Resources for the Future, Johns Hopkins University Press, Washington D.C.

3. Ehrlich, P. R., Ehrlich. A. (1981) Extinction: The Causes and Consequences of the Disappearance of Species. Random House, New York

4. Mooney, H., Ehrlich, P., (1997), Ecosystem services: A fragmentary history. in Daily, G. (edt), Nature's Services. Societal Dependence on Natural Ecosystems, Island Press, Washington

5. Dudley, N., S. Stolton, A. Belokurov, L. Krueger, N. Lopoukhine, K. MacKinnon, T. Sandwith and N. Sekhran, (2010), Natural Solutions: Protected Areas Helping People Cope with Climate Change. Gland, Switzerland: WWF International

6. March, J.A., (2012), Integrating Natural Resource Management into Disaster Response and Mitigation. In J.C. Ingram, F. DeClerck and C. Rumbaitis del Rio(eds), Integrating Ecology and Poverty Reduction: Ecological Dimensions. New York: Springer, 393-406

7. DG Environment, EU \& Stella Consulting, (2012), Report on the Costs, benefits and climate proofing of natural water retention measures, "EU policy document on Natural Water Retention Measures", WG PoM, 2014

8. Posthumus, H., Hewett C., Morris Jl., (2008), Agricultural land use and flood risk management: Engaging with stakeholders in North Yorkshire, Agricultural Water Management, Vol 95

9. Bronstert, A., Niehoff, D., and Burger, G., (2002), Effects of climate and land use change on storm runoff generation: present knowledge and modelling capabilities, Hydrol. Processes, 16, 509- 529

10.Николова, М., Недков, С., (2012), Рискът от Наводнения. ГИС моделиране на 
промените в околната среда за оценка на опасността от наводнения. Изд. ТерАРТ. C. 245. ISBN 979-954-9531-16-9

11.Horton, R., Ankeny, M.D., Allmaras, R.R., (1994). Effects of compaction on soil hydraulic properties. In: Soil Compaction and Crop Production, B.D. Soane and C.van Ouwerkerk, Elsevier, Amsterdam, The Netherlands.

12.Holman I.P., Hollis J.M., Bramley M.E., Thompson, T.R.E., (2003), The contribution of soil structure degradation to catchment flooding: A preliminary investigation of the 2000 floods in England and Wales, Hydrology and Earth System Sciences, 7(5), 754-765

13.Morris, J., T. Hess and H. Posthumus, (2010), Agriculture's Role in Flood Adaptation and Mitigation: Policy Issues and Approaches, in Sustainable Management of Water Resources in Agriculture, OECD Publishing, Paris. DOI: http://dx.doi.org/10.1787/97892640835789-en

14.Cooper, T., K. Hart and D. Baldock (2009), The Provision of Public Goods through Agriculture in the European Union, report prepared for DG Agriculture and Rural Development, Contract No 30-CE023309/00-28, Institute for European Environmental Policy, London.

15.Bateman Ian J., Richard T. Carson, Day Brett, Hanemann Michael, Hanley N., Hett T., Jones-Lee M., Loomes G., Mourato S., Özdemiroglu E., Pearce D., Sugden R. and Swanson J., (2002), Economic Valuation with Stated Preference Techniques: A Manual, Edward Elgar, Cheltenham

16. Vanslembrouck, I., van Huylenbroeck, G. and Verbeke, W. , (2002), Determinants of the willingness of Belgian farmers to participate in agri-environmental measures, Journal of Agricultural Economics, Vol. 53pp. 489-511 